\title{
ISLAMIC BANKS AND FINANCE AND THE POSSIBILITY OF AGRICULTURAL INVESTMENTS IN THE REPUBLIC OF SERBIA
}

\author{
Bahrija Kačar ${ }^{1}$, Jasmina Curić2 , Selma Ikić3
}

\begin{abstract}
Summary
Financing the economy and agriculture as well in the Republic of Serbia in recent past present was realized and has been implemented with the financial and credit support of the state, as well as through expensive commercial bank loans and financial leasing. Bearing in mind the productive resources, the importance of agriculture to the national economy and employment of the population, and that the financing of agriculture in the Republic of Serbia, at its current level of development, should be implemented with the support of the state. States should work towards the establishment of specialized agricultural banks and by legislation facilitate the arrival of financial institutions which will place funds at favorable conditions such as the Islamic financial institutions do.
\end{abstract}

Islamic financial institutions in the placement of funds-loans do not use the loan interest rate which is according to the Islamic beliefs unfair and unacceptable. The theoreticians of Islamic economy see an alternative in the fundamental values and teachings of Islam, the Quran and the Sunnah, which strictly prohibit interest.

Islamic bank can make certain comparative advantages in respect to the other domestic banks. It is in a position to establish a sound business relationship with clients from Muslim countries for the local companies to perform in their markets, as well as with the performance of companies from Muslim countries on the Serbian market. A further advantage of this bank we see in the fact that one of its founders would be the IDB - Islamic Development Bank - the leading development bank of the Muslim world, whose experience in the implementation of development projects in Serbia can be of great benefit. However, the largest Islamic bank has potential in the establishment and development of business

1 Kačar Bahrija Ph.D., Assistant, Department for Economic sciences, State University of Novi Pazar, Vuka Karadžića street nn, 36300 Novi Pazar, Serbia, Phone: +381 62333808 , E-mail: bahrijakacarnp@yahoo.com

2 Curić Jasmina Ph.D., Assistant, Department for Chemical - Technological sciences, State University of Novi Pazar, Vuka Karadžića street nn, 36300 Novi Pazar, Serbia, Phone: +381 6663152 70, E-mail: jasminacuric65@gmail.com

3 Ikić Selma M.Sc.,Associate, Office for Local Economic Development, City Administration of Novi Pazar, Stevana Nemanja street no. 2, 36300 Novi Pazar, Serbia, Phone: +381 62488 740, E-mail: selma.ikic@,novipazar.org.rs

EP 2017 (64) 3 (1081-1100) 
relationships and cooperation with a growing number of financial and other institutions whose operations are based on the principles of Shariah.

Key words: Agriculture, agriculture loans, Islamic financial institutions, Islamic banks

JEL: $G 21, Q 10, Q 14$

\section{Introduction}

This paper provides a brief overview of the importance of agriculture in the Republic of Serbia. It provides a brief overview of the ways of agricultural funding from the 80 s to the present day. Financing of agriculture, which has been conducted from the primary issue of the National Bank, agrar budget, specialized state financial institutions and financial leasing, has not yielded with the expected planned development of agricultural production.

In order to achieve the planned growth of agricultural production, it is urgent to include the funding of potential financial institutions such as funds of the European Union. Republic of Serbia as a candidate for accession to the European Union is entitled to five components. For financing of multifunctional agriculture the fifth is the most important component. Although Serbia had previously received funding for agriculture from the EU IPA funds, IPARD will bring new opportunities because it is aimed at rural development and provides direct support to farmers.

Another potential financial source of funding for agriculture is through Islamic financial institutions. The paper describes the principles which Islamic financial institutions work on. Islamic banks made the greatest contribution to the development of Islamic institutions . This paper describes the principles and financing of Islamic banks. There are four individual models of Islamic banks financing, within each of the model there have been listed funding methods ie. loans, and what is each model ie. method of financing suitable for. Which of these models are the most suitable bank loans for financing of agricultural production.

\section{Research goal, methodology and date sources}

The aim is to present the up-to-date way of financing of agriculture and recommend potential way of financing of agriculture in the Republic of Serbia. For this purpose, the modalities of financing and lending practiced by Islamic financial institutions ie. Islamic banks have been presented. Within the possible ways of funding through Islamic banks, the proposed are the forms of credit that by their characteristics correspond to financing of agriculture.

The paper uses analytical co-empirical methods, the comparative method, as well as a method of research at the table (desk research), through which the domestic and foreign literature dealing with the respective problem have been researched. Analytical coempirical methods are common for the researches in economic sciences and are based on the analysis of the experiences in the past. In particular, in this work, the forms of financing of agriculture in the Republic of Serbia in the post-war period up to 2016. Years have been analysed. In order to propose potential way of funding through Islamic financial institutions (Klincov et al., 2017), the conclusions of the researches based on the comparative method have been used. 


\section{The importance of agriculture in the Republic of Serbia}

The most important task of agriculture is to produce food for the people, and at today's level of development of science and scientific knowledge it can be considered that only agriculture is capable of producing basic foods for human consumption.

Due to the biological nature of agricultural production, natural factors have a significant impact on results in the production. As agricultural production takes place mainly in the open field, the effect of natural factors are largely beyond the reach of human power, and therefore it is not certain that the investments in agriculture will bring the appropriate profits, resulting in fewer investments of capital in agriculture, and therefore the development of entrepreneurship within it takes place slowlier.

Time of production in agriculture is relatively long when compared to the time of production in other sectors, because in crop production it is limited by vegetation cycles, and in livestock production by reproductive cycles. Due to these facts, the turnover of capital in agriculture takes relatively longer than in other industries. Due to that, the same quantity of capital at the same rate of profit, due to the different duration of capital turnover, will make different profits in agriculture, much less than in other industries. Therefore , the capital slowlier penetrates into agriculture. In agriculture, the production time does not coincide with the time of direct labor process, ie, the production time is much longer than the time of operation. Agricultural production is for a certain time under the influence of natural factors, under whose influence the plants go through certain biological, chemical, physical and chemical processes.

Due to such a character of agricultural production in crop production it leads to the seasonality, which is reflected in uneven exploitation of labor and resources during the year. Production cycles in many branches of agriculture are different, which conditions the manners of financing ie credittting of agriculture.

The most important characteristics of agriculture, which determine the specificity of the credit policy are:

- low accumulative capacity of agriculture

- biological character of plant and animal production, which causes a slower turnover of capital (funds)

- a significant impact of natural factors on the volume of production which results in higher risk investments

- lower efficiency of investments in a number of agricultural projects

- the existence of multiple forms of ownership of agricultural entities that require different approaches to assessing the creditworthiness of investment funds.

Agriculture is a very important economic activity in the Republic of Serbia, which has an economic, social, and political importance. In Serbia, $85 \%$ of the territory is considered the rural area which is inhabited by $55 \%$ of the total population. Based on the results of the Census of Agriculture in 2012 (National Bureau of Statistics, 2013, Volume I, p. 13) there 
are 631,552 agricultural households in Serbia that cultivate a total of 3,437,423 hectares of agricultural land. Prevailing in the agricultural household structure are family households, which constitute $99.5 \%$ of total, with only $0.5 \%$ of farms that are owned by legal entities and entrepreneurs. In the structure of the property, private property accounts for $80 \%$ of the total area of agricultural land. The average size of agricultural holdings in the European Union is about 20 acres, and in our country semi-sustainable households prevail, ie. $47 \%$ of households use up to two hectares of agricultural land. Small size of the estate hampers the development of competitive production and reduce operating costs, which requires greater funding sources. Also, domestic agricultural production is characterized by low productivity, and thus the price uncompetitiveness, when it is about extensive crop and livestock production. There population in rural areas is rapidly declining. According to the Institute for the Study of the Village, and on the basis of the census of 2011, 1,200 villages in the Republic of Serbia are in the process of extinction. Reasons of "exodus" of the population are rural underdevelopment and lack of jobs, which could be solved by adequate funding of rural development.

In Serbia there is a lack of development and export-import banks that can accompany major clients and provide them with quality and affordable banking services. The lack of developmental financial institutions is one of the serious development barriers. Unregulated markets iof agricultural products cause lower revenues that small and average agricultural producers earn on them, and thus a greater need for external financing sources. The state has an inadequate role in terms of low percentage of allocations from the "state budget" for the agricultural budget. The agricultural policy had the adverse impact on the economic situation and financing of local agriculture which in the late transition period was inconsistent, and without the required continuity and predictability. In the period before the transition and in the first years of the transitional period it had been extremely protectionist. In 2003, the agricultural policy was "turned from protectionist into liberal and rather abruptly, left a devastating negative impact on agriculture, which primarily reflected tin the unresolved problem of financing of this economic activity" (Pejanović, Radovic, 2011, p . 37). Domestic agriculture in the pre-transition period was the victim of price disparities in agri-nutrition and industrial products.

\section{Forms of financing of agriculture in the republic of Serbia}

Financing of domestic agriculture until 1994, had been entirely dependent on the state. Financing of Agriculture was conducted from the primary issue of the National Bank, which was performed so that the central bank each year would form a selective credit potential on the basis of which it placed short-term loans to commercial banks. From these sources, commercial banks were granted agricultural loans at the discount rate, which was twice or even five times lower than the interest rates on the financial market. This method of financing has left a negative impact on the domestic financial, monetary and economic system, because of the inadequate system of its control, which had been entrusted to the commercial banks.

The share of primary production in the gross domestic income increased from about 10 percent at the end of the eighties to around 20 percent in 2000 . Primary agricultural products represent almost 27 percent of Serbian exports, and employ more than 23 percent 
of the workforce. These numbers are, unfortunately, more a reflection of the deep crisis of the industry and the services sector underdevelopment than a proof of the strength of our agriculture. It is still one of the least productive in Europe, with a vaguely defined strengths and many weaknesses. "

Agricultural budget, as one of the sources of financing of agriculture was established by the Decision on the establishment of the agricultural budget which was passed in late 1995, and it became a part of the state budget in 1996. On the proposal of the Ministry of Agriculture, Forestry and Water Management, in accordance with the Law on Budget of the Republic of Serbia, the Government determines the amount of the agricultural budget every year.

Law on Incentives in Agriculture and Rural Development stipulates that the agricultural budget can not be lower than 5\% of the budget of the Republic of Serbia, as of 2014 (Law on Incentives in Agriculture and Rural Development, 2013).

Table 1. Agrar budgets of the Republic of Serbia for the period of 1996-2016.

\begin{tabular}{|l|r|r|l|}
\hline Year & $\begin{array}{l}\text { Total budget of Republic } \\
\text { of Serbia (in mil. RSD) }\end{array}$ & $\begin{array}{l}\text { Agrar budget of Republic of } \\
\text { Serbia (in mil. RSD) }\end{array}$ & $\begin{array}{l}\text { Share of agrar no budget in total } \\
\text { budget RS (\%) }\end{array}$ \\
\hline 1996 & $10,240.2$ & 900.0 & 8.3 \\
\hline 1997 & $13,821.0$ & 828.9 & 6.0 \\
\hline 1998. & $16,807.5$ & 975.3 & 5.8 \\
\hline 1999. & $17,640.7$ & 878.2 & 5.0 \\
\hline 2000 & $32,702.4$ & $1,823.4$ & 5.6 \\
\hline 2001. & $127,339.9$ & $3,940.1$ & 3.1 \\
\hline 2002 & $177,600.0$ & $7,640.0$ & 4.3 \\
\hline 2003. & $271,800.0$ & $10,990.0$ & 4.0 \\
\hline 2004. & $329,300.0$ & $20,140.0$ & 6.1 \\
\hline 2005. & $432,900.0$ & $18,980.0$ & 4.4 \\
\hline 2006. & $505,820.1$ & $27,543.9$ & 5.4 \\
\hline 2007. & $595,517.8$ & $26,095.8$ & 4.4 \\
\hline 2008. & $695,959.1$ & $32,895.4$ & 4.7 \\
\hline 2009 & $719,854.1$ & $26,690.4$ & 3.7 \\
\hline 2010. & $825,884.9$ & $31,577.9$ & 3.8 \\
\hline 2011. & $824,575.9$ & $33,676.0$ & 4.1 \\
\hline 2012 & $1,018,633.4$ & $40,876.7$ & 4.0 \\
\hline 2013. & $1.040 .014,3$ & $44.699,5$ & 4,3 \\
\hline 2014. & $1.110 .121,0$ & $45.427,2$ & 4,1 \\
\hline 2015 & $1.082 .988,2$ & $45.308,2$ & 4,2 \\
\hline 2016 & $1.085 .308,4$ & $40.465,7$ & 3,7 \\
\hline & & & \\
\hline
\end{tabular}

Source: http://www.parlament.gov.rs/upload/documents/3204-15.pdf (Zakon o budžetu republike srbije za 2016. godinu), http://www.parlament.gov.rs/upload/documents/4598-14.pdf (http:// www.parlament.gov.rs/upload/documents/3204-15.pdf (Zakon o budžetu republike srbije za 2015. Godinu), Author's calculation. 
For the development of agriculture and rural development in the Republic of Serbia, it is necessary to increase the share of agricultural in total state budget in the future, and to provide that incentives and support to rural development have greater share.in the qualitative structure of the agricultural budget .

Through the Ministry of Agriculture and Environment of the Republic of Serbia and specialized state financial institutions, the agriculture loans have been implemented since 2004. This method of crediting of agriculture is realized through commercial banks operating in the Republic of Serbia and the source of loan funds is agrearn budget, with a low interest rate. Only registered households have the right to use the loan funds.

Lending to agriculture with the support of the state is implemented through the Ministry of Agriculture of the Republic of Serbia and the specialized state financial institutions. The support is implemented through commercial banks through short-term and long-term loans with low interest rates and the source of credit is agrar budget.

Specialized state financial institutions have implemented lending to agriculture and rural development with credit portfolio on favorable terms and low interest rates, by that means: the Development Fund of the Republic of Serbia, Fund for Agricultural Development APV, Development Fund APV, and partly by Capital Investment Fund of APV . Guarantee fund for AP Vojvodina has a function to provide to agricultural as well as other companies obtaining of the bank guarantees under favorable conditions.

Commercial banks participated in the placement of their credit resources in the development of agriculture. The credit investments in agriculture did not have a significant share in total loans of commercial banks in the initial period. In the last ten years, there has been a noticeable increased interest in lending to agriculture. The loans that commercial banks granted to agricultural entities in the Republic of Serbia, in the entire previous period, were characterized by: (1) high interest rates; (2) application of the currency clause; (3) unconformity of lending with seasonal nature of the agricultural production; (4) short credit terms ; (5) requirements for the high insurance of the credit; (6) the strict selection of the borrower; (7) the high cost of credit insurance; (8) the absence of or too short grace period; (9) the obligation to pay a one-time loan processing costs; (10) most of the banks interest was calculated on the full amount of the loan, not just on the outstanding amount and (11) failure to show the effective interest rates in credit conditions

Financing of agriculture is done through financial leasing on the basis of the Law on financial leasing, which was adopted in May 2003. Financial leasing is a relatively new but very present way of financing agriculture. Leasing has had a very important role in financing investments in agriculture and, above all, in the procurement of agricultural machinery and equipment.

Financial leasing in the past decade has had a very important role in financing investment in agriculture and, above all, in the procurement of agricultural machinery and equipment. Advantages of financial leasing as a means of financing agriculture are: (a) compliance of repayment to seasonal nature of agricultural production; (B) a simple and fast realization 
of the procedures on financial lease contract due to the fact that the leasing companies generally have a business cooperation with suppliers of lease, which results in faster procedures and to a reduction in transaction costs as well;

(C) possibility ofleasing used agricultural machinery and equipment;(D) this source is particularly suitable for start-ups, as well as the individual agricultural producers who do not have a "credit history"; (E) it is favorable for agricultural entities that do not have high creditworthiness, but they need a machine of a larger value. In addition to these advantages, disadvantages of leasing as a means of financing agriculture should also be noted The disadvantages are, firstly, related to the additional costs which leasing causes, and that are the costs of insurance of financial leasing object and the costs of value added tax to be paid and the costs of interest calculated on the basis of financial leasing contracts (Vladisavljević et al., 2017).

\section{Potential ways of financing agriculture in Serbia}

One of the potential ways of financing agriculture are the Pre-accession funds of the European Union - for financing of multifunctional agriculture the most important component is the fifth, ie IPARD program. The Republic of Serbia is entitled to around 200 million euros per year from pre-accession EU funds, in the period 2014-2020, . Financing of agriculture from the IPARD program, according to the procedure of the European Union, is being implemented on the principle of co-financing. Cofinancing from IPARD fund is carried out: (a)for the measures from the axis 1 of the co-financing is at least $10 \%$ and a maximum of $50 \%$ to $75 \%$; (B) for the measures of co-financing axis 2 it is at least $25 \%$ and a maximum of $55 \%$ to $80 \%$; (C) for the measures of the co-financing from the axis 3 it is at least $10 \%$ and a maximum of $50 \%$ to $75 \%$. Also, IPARD program anticipates that public sector participation may be a maximum of $50 \%$, while the rest of the means should be provided from the private sector. For the implementation of the potential ways of financing agriculture and rural development there is need to accredit appropriate operational structures and solve the problem of pre-financing due to the fact that the funds for projects on the basis of which it is applied for funds from IPARD program are approved by the system of reimbursement.

To ensure pre-financing for projects that will be co-financed from IPARD program and also for financing of the development of: (A) primary agricultural production; (B) multifunctional agriculture; (C) processing agricultural sector based on the entrepreneurship and micro businesses (mini oil plants, slaughterhouses, dairy and alike.), it is necessary to establish agricultural specialized bank.

On the first of March 2012, we have acquired the status of EU candidate.. For the preparation and accreditation it takes 1.5 to two years. So the start of use is expected at the latest by the end of 2013. If we get the first funds for 2012, we could use them until the end of 2015, on the basis of the $N+3$ (budget plus next years to pay). Since at the beginning of 2017 we are much further from IPARD funds than in 2012. year, in the best case scenario we could use the first funds in 2018. So far, 125 million euros in investments from EU have been irreversibly lost. 
Other potential way of financing agriculture is through Islamic financial institutions ie. Islamic banks. Due to its character, Islamic banking could contribute to filling the said gap.. This would contribute to the development of not only Islamic banking in the Republic of Serbia, but also the overall economic development of the Republic of Serbia.

\section{Principles of financial institutions}

In a secular society where the laws are made by the will of individuals or groups of people, and as such are subjects to changes, in Islam laws are enacted or imposed by God (Allah) by the revelation, and therefore eternal and beyond the means of man-intervention and change. A set of unified legal norms that are the basic regulation or the supreme law in Islam is called Sharia.

The Islamic economy is a branch of economic science where the studies have been carried out in the area of the Islamic economic system and its impact on economic changes and decisions.

Basic items of Islam are also the foundations of Islamic economics and are defined by four basic categories of Islam: 1. tawhid (tawhid - God is one and unique). It rejects obedience and humility of man to other people and confirms complete submission of man to God as the sole and absolute ruler of the world. 2. rububijjet (rububiyyah - Divine ditribution of the resources and managing things by their perfection). This is one of the fundamental laws which confirms the divine origin of the resources of the earth with their mutual obligation of equitable distribution. 3. Hilafat (khilifah - role of man as well as the governor of God-Khalifa on earth). It defines a person's status, role and responsibility. And the fourth category, Tezkije (Tazkiyah - self-purification and growth). Tezkije principle is the basis from which the concept of the total Islamic development has been derived. It helps a man to get rid of its internal pressure and to achieve a high level of freedom and emancipation. The result is falah - material and spiritual progress in this world and the post-mortem world.

The verses relating to economic issues are distributed throughout the Qur'an, while in Sunnah they emerged as a response to current life issues and there are about forty thousand laws, orders, instructions and statements attributed to the Prophet.

Islamic approach to lending recognizes the need for borrowing with interest, but only as a last mean and with strictly defined conditions. One can borrow money with interest only when one is forced by the utter the necessities of life. In this case, the sin falls on the lender, not the borrower. This opinion is based on verses from the Koran pertaining to the prohibition of certain things accurately, but whose use, in extreme cases, however, is permitted.95 " It is forbidden to you to eat dead meat, and blood, and flesh of swine, and what is slaughtered in someone else's name, and not in the name of Allah ... and to one who is forced, when hunger strikes, with no inclination to sin, Allah will forgive and be compassionate "(5: 3) 92nd Islamic finance is built on the basis of Islamic learning in which "money by itself can not make money." Islamic finance, and within them, Islamic banks reject interest rate mechanism and interest as the cost of capital, which represents a significant difference compared to conventional banks that have upon the very interest built 
up their core business and development philosophy.

In order to create new value, the money has to be invested, ie. has to be put into operational business activities, whether it is a manufacturing, service or trade. Increase of wealth from business activities will not be "passed" if it is acquired on the basis of monopoly prices, or various other forms of illegal activities such as interest, corruption, blackmail, etc. Islamic finance is built on the fundamental principle of participation in the distribution of profit or loss from business partners.

\section{Islamic banking}

Islamic banks have the most important role in the current development of the Islamic financial system and they gave the largest contribution to the financing of economic development of Muslim countries.

The growth of Islamic banks in the last two decades is impressive and there is no doubt that in the future it will continue. The broad base of their clients, the volume of work they perform, as well as constantly raising the level of training of staff is the basis for the belief that it is not a simple and fleeting phenomenon. Credits for the development of modern Islamic financial system in large part can be taken by the theoreticians of Islamic economy. Islamic economics basically seeks to embed the ethical and moral principles of Islam as a religion into economic theory . The benefit of the community is not necessarily subordinate to the welfare of the individual, and it seeks to reconcile these two "interests" and to exclude competitive relationship between them.

Modern Islamic banking is linked to the end of the nineteenth and beginning of the twentieth century. The first Islamic financial institution, as a forerunner of modern Islamic bank was founded in 1963 in Meet-Ghamr Dakahlia province in Egypt.

A strong impetus to the development of Islamic finances was the establishment of the Islamic Development Bank (IDB - Islamic Development Bank) based in Jeddah, Saudi Arabia. In the development of the Islamic financial system, Islamic financial institutions have a crucial role.In the world today, there are over 200 different Islamic financial institutions operating in over 50 countries on all five continents, and particularly in the Middle East, Africa, Southeast Asia, North America and Europe. Beside them, there are a number of non-bank financial institutions: Islamic money market, Islamic mutual funds, Islamic Stock Exchange and Islamic insurance companies operating on the principles of Shariah.

\section{The objectives and principles of the Islamic financial system}

Objectives of the Islamic financial system are identical to the goals that traditional financial systems have. They are reflected in the mobilization and allocation of financial resources necessary to fund the development of national and regional economy. The objectives are realized within the financial institution, by the means of financial instruments and mechanisms. The realization of the objectives of Islamic finances significantly differs from conventional financial institutions. Islamic finances are built on the fundamental principle 
of participation in the distribution of profit or loss, or the principle of risk sharing between business partners. Islamic finances, and within them, and Islamic banks reject interest rate mechanism and interest as the cost of capital, which represents a significant difference compared to conventional banks that have the interest built up in their core business and development philosophy.

One of the fundamental principles of the Islamic economic approach, therefore the Islamic banking is justice or fairness. In addition to this principle, there are the following principles, namely: absolute prohibition of paying or charging of interest in any form; obligation to share the profit or loss; inability to profit without taking risks, this refers to the work and the capital; prohibition of creating a "cash money", the money represents only an intermediary that helps in the exchange; prohibition of gambling, excessive risk, speculation and uncertainty; prohibition of financing or work with products or activities prohibited in Islam.

The Islamic financial system in general, and Islamic banking in particular, is increasingly contributing to the financing of economic development, becoming a significant participant in global financial markets, but in our country they are not appreciated at all.

\section{The principles of Islamic banking}

One of the basic principles of Islamic banking is an absolute ban on the use of interest rates in the financial operations of Islamic banks and financial institutions have their business philosophy based on business arrangements that include participation in profit or loss, and other, Sharia allowed, funding models.

The grounds of the Shariah are: Tawhid, Risaleh, Ahiret. Sharia law is not law in the conventional sense of the word. It presents a comprehensive and coherent set of legal rules, derived from God's revelation, which, through a system of prohibitions and orders regulates the relations in all spheres of human activity. Sharia has four main sources:

Quran - holy book of God or in which there is no doubt, which is the first and most important source of law for all believers-Muslims.

Sunnah - the tradition and customs of the last Prophet of God through words, proverbs, sayings and deeds.

Ijma - consensus among Islamic jurists on a particular legal issue.

Qiyas - analogy as a fourth or a secondary source of Islamic jurisprudence.

Property rights in Islam are considered from different aspects, and they are the one of the topics which the theoreticians of Islamic economy paid a special attention to.True, genuine, real or beneficial owner. In the Qur'an we find a clear answer: "Allah is everything in the heavens and on earth" (2: 284).

The man manages assets with confidence in accordance with the principles of Shariah and is responsible to Allah. The man has an obligation to use revenues acquired on the basis of assets "entrusted" to him in the approved manner and for lawful purposes, and they 
should not be used in a way that is forbidden and for the purpose which is not allowed. The man has the right to enjoy the material and sensual pleasures as long as it is within the boundaries of religion and while it does not distract him from thinking about God. The primary economic motivation of man in Islam is expressed through its contribution to maximizing the pleasure of God.

Acceptance of profit as the only measure of quality evaluation of a project, from the point of Islamic economics, is not acceptable. By its nature the profit tends to its magnification and is directed to the segments in which it will likely increase capital the fastest. It often uses exploitation as an instrument of its enlargement and negative effects of these must be neutralized by other categories of Islamic economics. Islam puts certain restrictions on business transactions in the financial market. They can be divided into five basic groups: Prohibited goods, services and activities: Islam prohibits the production, trade, consumption and other activities to certain goods and services that are harmful to the individual and his family, and for society as a whole. Prohibited products, services and activities as alcohol, intoxicants, drugs, pork, earning monopoly profits, corruption and bribery, abuse, pornography, gambling, speculation, fraud, terrorism and other products, services and activities that are prohibited under Shariah.

The prohibition of interest (riba): Islam strictly forbids interest and business interest. " $O y e$ who believe, fear Allah and cancel the rest of the interest, if you are believers." "If you do not, there you have it, let him know - the war from Allah and His Messenger! And if you repent, another principal possessions your will remain, not making any damage, nor will damaged to be. "(2:278.279) The goal is to prevent injustice by which the creditor transfers all the risk to the debtor, which is contrary to the fundamental teachings of the Quran ' an and the Hadith. "Allah has cursed those who take interest, those who pay, those who write the contract, and those who witnessed the contract." (Ahmad, Abu Dawud, al-Nesa, Ibn Majah and al-Tirmidhi).

Prohibition of transactions that contain a high degree of uncertainty (gharar): in businesses in which the partners do not have enough knowledge on the subject of buying and selling. The purpose of the prohibition is based on the fact that illegal methods contain elements of fraud, which can lead to misappropriation of another's property, or conflict and hatred among people.

Prohibited manners of trade: refer to the type of purchase Refers to the buying and selling that implies: paying the price and delivery of goods in the future at prices that are now established (bay-Adien-bidi), or the sale of debt to debt. Permitted ways of buying and selling include: delivery of goods today and pay the price tomorrow, or within three to five days (Bai'e-al-hal), delivery of goods today and pay the price later date (bai 'muajjal) and paying the price today and the delivery of goods later date (bai 'as-Salam).

Other prohibited activities: Refer to the question of "final intentions" or "end user" of certain business activities. They will be allowed if the ultimate intention is not prohibited or end user is not debatable. The example can be selling of the land on which the buyer intends to build a factory that will produce prohibited goods, to provide prohibited services or perform 
prohibited activities or selling products to those who intend to produce alcoholic beverages out of them. Islam does not deny the economic and other inequalities among people. It is natural and inherent in human beings and social systems. In the Qur'an, there is no evidence that seeks to eliminate inequality and to establish order in which everybody would each receive an equal share of economic wealth and Islam recognizes and tolerates a certain income inequality because all men are not equal in character, abilities and social contribution.

\section{Models of financing in Islamic banking}

Islamic banking system uses a larger number of financing models and they can be divided into three groups: (1) financial instrument mobilization of bank resources, (2) financing models, and (3) the instruments for the implementation of neutral banking operations.

Neutral banking transactions, item number three and instruments for the implementation of these operations are identical to those in the practice of conventional or traditional banks and are used in accordance with the international banking practice.

In the financial models mobilization of bank resources in Islamic banking, the bank does not pay interest to depositors. It offers depositors the participation in the distribution of profit or loss to be incurred through various banking business operations. The two main sources of funds of Islamic banks are: (1) demand deposits that are directly related to the current payment transaction and savings and (2) deposits for investments, which represent the main source of funding for banks and are intended for the financing of various projects.

1. Debit Accounts (Al-Wadi'ah contract) function the same like demand deposits. Savings Accounts (Al-Wadi'ah contract) are related to savings deposits (savings) of the population. Islamic Bank offers four different ways of depositing funds on these accounts: -acceptance of the deposit on the principles of trust, where the depositor of the bank is asked to give consent for the use of inputs to the account, with a legal obligation to return the deposit and unmandatory participation in the distribution of the realized profit if any, - the admission of saving deposits with the power bank to invest and profit share as a reward to the depositors according to the period and the amount of funds located on the account; -Treatment of savings deposit as qard hasan (a benevolent loan) which means allocationof all cash or noncash effects to the bank - accepting savings deposits in joint investment accounts and their treatment as investment deposits.

2. Investment account (Profit and Loss Sharing PLS-accounts), that can be opened by individuals or companies for a certain period. The bank, concludes an agreement with depositor on the principles of Al-mudaraba where the bank appears in the role of "entrepreneur", and depositor in the role of one who provides the necessary capital. The contract determines the amount or proportion of distribution of profit or loss.In this group accounts occur in several forms, namely: Common / General Investment Accounts, Timebound investment accounts and Indefinite time investment accounts Special investment accounts (Profit and Loss Sharing-PLS accounts) allow depositors to deliberately direct their deposits for financing of specific projects. The bank appears in the role of representative or agent of the investor. 
Models of financing. Islamic banks in their work use a few basic models of financing based on Shariah principles, namely:The first model of funding that is in fact based on a model of sales (ajal)Second funding model, which is implemented as a loan or leasing (injara)The third model of financing represents a business partnership based on joint participation in the distribution of profit or loss (Musharaka)The fourth model of funding is based on the joint participation in profit-sharing (mudaraba, muzara'a, musaka'a ...)

Graph 1. Models of financing of Islamic banks

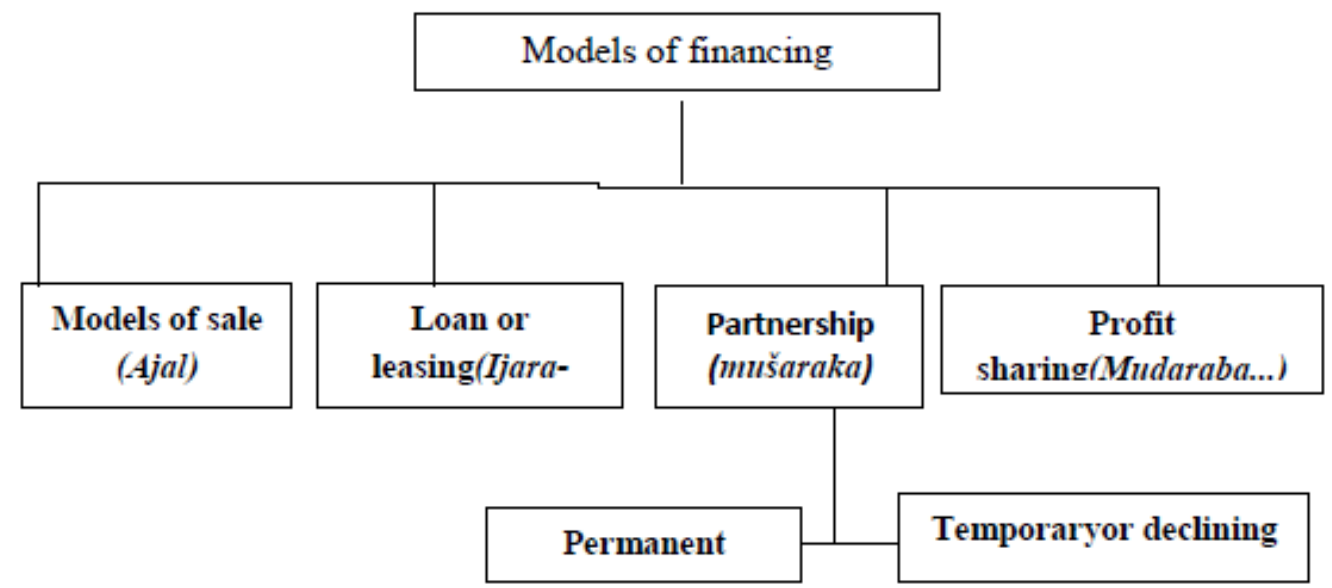

Source: Hadžić F., (2005) Islamic Banking and Economic Development, Faculty of Economics Sarajevo, page 169.

Funding models from the aspect of the period of financing can be divided into:Short-term funding which include Murabaha as a financing model. Medium- and long-term financing which includes mudaraba, Musharaka, Ijarah and istisna'a as models of financing. Model of financing based on sales (Ajala) represents the first group of models of financing, and is composed of more than one method of sale which are presented in the following graph. 
Graph 2. Methods of sales as one of the financing models (model-sales ajal)

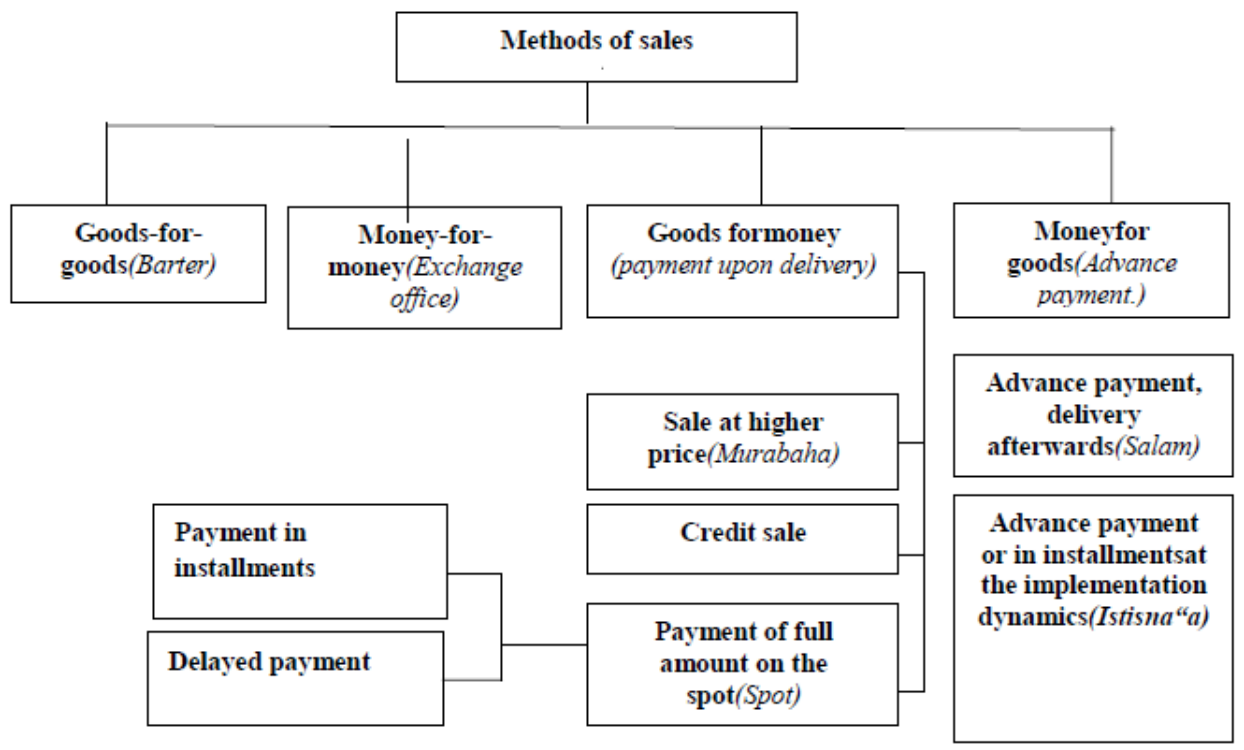

Source: Hadžić F., (2005) Islamic Banking and Economic Development, Faculty of Economics Sarajevo, page170.

One of the models of financing based on Murabaha sales fall (bai-Mujal, mark-up and cost-plus-based financing), is one of the most important model of financing which Islamic banks use in their operations. This is a sale contract of in which goods are sold at cost plus a certain profit. The seller is required to disclose to the buyer the purchase price of the goods and the profit that will be occur with his business. This is the kind of trade where the client requests the bank to perform the purchase of necessary goods, products or equipment investment.for him. The Bank assumes the responsibility, to buy goods with the properties specified by the customer under favorable conditions,. The bank sells to the client goods at a price which covers the purchase price, plus a commission or income of the bank in this business. Height of banking fees or profits previously agreed with the client and the practice of Islamic banks rarely exceeds $10 \%$ of the purchase price of the goods. The client pays the goods to the bank on the basis of repayment which is made in installments with the agreed allowances in certain periods of time. Murabaha is particularly suitable for the short term trade financing. This model is suitable for financing of consumers when purchasing consumer durables, real estate, apartments and houses.

Another significant funding model based on the sale is the Salam (Bay 'salam - Purchase with deferred delivery) a sale of goods for cash in the entire amount which will be delivered of done later under the terms defined by the contract.

Salam in agriculture is a suitable model when the bank pays to farmers agreed price in advance, with provided later delivery. Because of the specificity of agricultural production in the agriculture production time takes longer and is very different from the time of the immediate work process. Unlike industry or any other economic activity, in agriculture 
there is the biological character of the subject of work, ie base material. Biological character of the subject of work inthe agriculture distinguishes this from other economic activities in the fact that the weight of the base material, plants and animals, increases with the time thrrough their growth and development. Respect of the technological maps involves the use of agro-technical measures in a precise, optimal timeframe. On the other hand, the growth and development of plants and animals is continuing. In perennial crops and in certain lines of livestock production, it is sometimes necessary to wait years or more on the end result ie. the finished product, in regard to the initial investment. This specificity of agriculture, which is also known as seasonality, causes direct economic implications reflected in the slow turnover of capital.

Salam as the model is in use and in construction, trade, financing of industrial production, handicraft production and business activities of small and medium-sized enterprises.

As salam model variant bai-muajjal also appears by which the seller allows the buyer to pay for goods at a projected future price in full or with a calculated repayment. Fixed price can be equal to, higher or lower than spot prices. Bai-salam and muajjal are practically Murabaha financing model derivatives.

Istisna'a (Bay'al-istisna) To implement this model, it is necessary to fulfill two conditions, namely:

- that at the time of concluding the transaction the subject of trade physically does not yet exist and

- it is not necessary to pay the full amount in advance, although the job can be fully paid in advance.

The Islamic Bank may appear in the role of an intermediary between the seller and buyer ny financing business. Also in this case two independent or related istisna'a contracts must be signed.

This funding model is not used in agricultural production, where we use salam contract, but is used for the realization of small (consumer goods, houses, etc.), as well as large projects (schools, hospitals, residential buildings, industrial plants, factories, turnkey projects in the field of high technology, process manufacturing, production of aircraft, ships, infrastructure facilities, etc.).

\section{Models of financing that are realized as a loan or leasing}

Ijarah (Ijara - Leasing), is a business relationship in which the bank buys items for future rental and lease and rents them to their clients. This is a classic "leasing" business. During the term of the lease Bank, as owner of the lease, transfers the right to use on the user. During the lease period the user, in addition to the lease,may pay part of the cost of the leasing object. After expiration of the contract equipment is returned to the owner or ownership is transferred to the user, or the user buys the equipment concerned.

Islamic banks differ two types of Ijarah or leasing operations, as follows:

EP 2017 (64) 3 (1081-1100) 
-Operating Ijarah type involves the bank purchasing or buy certain assets or equipment that would later lease to interested users. Operating Ijarah work is used for rental property or expensive equipment which, due to high prices, users are not able to buy.

It can be used in industrial equipment, agricultural machinery or production and business facilities.

-Ijara business with purchase (Ijara-wa-iqtina) is similar to the operating-Ijarah financing model, except that in this case property or equipment, after the expiry of the rental period (especially after conclusion of the contract) i sold to the user of the rent.. It represents the sale with deferred payment. Property or equipment is purchased per the request of the customer, so that the whole business is burdened with less risk of operating Ijarah transaction. The Bank will calculate into its selling price and a certain level of profit that will be previously agreed with the lessee. This form of Ijarah transaction is used for financing the purchase of real estate, computer and other equipment, machinery and the like. Model poslovnog partnerstva na bazi zajedničkog učešća u podeli profita ili gubitka

\section{Model of business partnership based on joint participation in profit sharing or loss}

Musharaka (shirka- partnership; Venture Capital Finance) is a business relationship between a bank and its client for the successful implementation of specific business activities. The bank and the entrepreneur or more of them together participate in financing investment and jointly run the business. This is a kind of "joint venture" - mutual investment. The partnership agreement shall govern the type of business framework in which the work will be completed, its duration and the distribution ratio of profit to be made in a specific business. Distribution of profit or loss will be realized upon completion of the transaction, at the end of the financial year, or in other terms that the partners agree. In the case of loss, it is charged from invested assets, which, after its deduction are returned to each of the partners. Profit which the bank realizes is directed a profit-pool of a bank. If the loss is incurred, the bank will cover it from the same pool-a.There are two basic forms of Musharaka as follows:

Permanent Musharaka(Equity Permanent Partnership) is a permanent share resulting from the bank's ownership of share in the capital of the joint venture. By the ownership of equity the Bank acquires the controlling rights and participates in the distribution of dividends in accordance with the share in the shareholders' equity of the company. If the company does not make a profit, it is clear that there is no distribution of dividends, and the reported loss will be covered at the expense of capital.

Temporary or decreasing Musharaka(Diminishing Equity Partnership) is a gradual decrease in the share of the bank or equity partner in the joint venture. The contractual relationship is based on participation in the equity of the company at its inception with an agreed schedule to reduce its participation, ie. Bank transfer ownership to other partners or shareholders. In proportion to its participation realized dividends are awarded to it.Musharaka financing model is especially applicable in agriculture and industry, more often in small and medium-sized enterprises than for large ones.The fourth group is a partnership based on joint participation in profit-sharing (mudaraba, muzara'a, musaka'a ...) 
Mudaraba(Al-qirad, Al-muqarada, Profit Sharing, Trust financing), a special business arrangement between the bank (rab-al-maal) and the entrepreneur (mudariba) in which the bank appears only in the role of financier of a joint project without active participation in management and its practical realization.

An entrepreneur is the one who invests the idea, knowledge, labor, capital goods and equipment, and everything else that is necessary for the initiation and implementation of a particular business. The Bank does not enter into the management and implementation of practical work, but when concluding a contract it may, in cooperation with the entrepreneur, define certain terms that contracting parties shall respect. This funding model means that partners share the profits according to previously agreed percentage share. In case of loss, it is always and only borne by the owner of the invested capital (in this case the bank). It looses a part of the invested funds, a mudarib looses own effort, and part of the material and intangible assets. In the case of loss, diligence, professionalism and integrity mudariba are the ones which are evaluated. If these criteria are not met mudarib bank is obliged to compensate the damages. The concept of Musharaka is a model of participation in profit or loss, while muradaba is a model of participation in profit.

Mudaraba found its application in various segments of industrial production, crafts and trade. Because of the high risk which has burdened the operating principles of mudaraba, its implementation has been quite reduced lately.

As a variant mudarabah financing model there appear the two ones that are used in the field of agriculture, and operate on the principles of allocation of yields or of the crops. Thus, there are:

Muzara'a - one party gives or provides the soil (seed, fertilizer and machinery), and other labor and management. After the harvest yield is divided according to the previously agreed sizes.

Musaqah - one party provides the land with planted fruit, and other labor and management. After riping and collecting fruits, the yield is divided according to the previously agreed sizes.

Today, the provision of banking and investment services on the principles of Shariah is implemented in several ways:

- One way is that Islamic banks provide Islamic banking services both in Muslim countries and Western countries markets. They are established as independent banks or branches of Islamic banks and they offer services of Islamic banking or investment to their clients

- Another way is offering Islamic banking services to clients through the Western conventional banks

- The third is that conventional banks in the West open the "Islamic windows" for the provision of Islamic banking services on the financial market in Western countries and in Muslim countries establishing their own offices or independent banks in Muslim countries that operate on the principles of Shariah. 


\section{Conclusion and recommendations}

Today, developing countries including the Republic of Serbia, are facing a serious debt crisis. Thei debt in the last ten years has been more than doubled. The biggest part of the debt problem includes the high cost of its maintenance. Annual interest payables are almost equalized with the obligations of return on equity. New borrowings are mainly directed to settling the old debt.

The Islamic financial system certainly has good prospects and widespread use in the developed economies and with better connection with finance and real economic sectors it will achieve stable growth and economic security of all participants.

Islamic banks with the change the legislation in the European and other countries and in the Republic of Serbia as well will get equal statusl as conventional banks. Then, they will be able to realistically assess their financial instruments based on Sharia versus conventional financial instruments.

Experience of changes in legislation and the work of Islamic banks represent a hybrid between commercial and investment banks. With the development of new financial instruments they will be able to a greater extent to meet the needs of economic and noneconomic entities, which will contribute to the minimization of risk and increased interest in investing in these banks. Financing through Islamic banking, where the banks appear as partners both in financing and in the distribution of profit or loss (Musharaka), the distribution of profits (mudaraba) or calculation of the commission, in accordance with the previous agreement and the signed contract. For financing of agriculture because of its specificity significant is a Salam model of financing Islamic banks. In addition of this model funding model known as Ijarah is also significant, where the bank buys an item that it would later lease to its future clients..

\section{References}

1. Arnautalić E. (2015): Islamic banking-phenomenon of modern society, available at:http://poslovnisvijet.ba/islamsko-bankarstvo-fenomen-modernog-drustva (1.4.2016)

2. Bakšić E. (2012): Islamsko Bankarstvo, available at: http://www.zeriislam.com/ artikulli.php?id=2452 (02.27.2016)

3. Bozidar, Đ. (2007): When it will we be better, publishers, "Official Gazette”, B92, Blic, The Economist, p. 71-73, 120

4. Hadžić F. (2005): Islamic Banking and Economic Development, Faculty of Economics Sarajevo.

5. Hadžić F. (2016): available at: http://www.bbi.ba/bs/static/islamskobankarstvo $(02 / 27 / 2016)$

6. http://www.islamic-banking.com/islamic banking principle.aspx

7. http://www.islamic-banking.com/profit_and lose_sharing.aspx 
8. http://www.islamic-banking.com/what is ibanking.aspx

9. Karić, E. (1995): translated, The Qur'an, Bosanska knjiga, Sarajevo.

10. Klincov, R., Majstorović, A., Miloradić, J. (2017): Vrednovanje rizika u finansijskom menadžmentu, Oditor, Vol. 3, No. 1, pp. 114-125.

11. Korkut, B. (1992): translated,The Qur'an, printed by order of hadimul-Haramain King Fahd Ibn Abdul-Aziz Ali King Saud of Saudi Arabia in the Complex Hadim1-Haramain-S-Šerifejni-1-Melik Fahd for the printing of the Mushaf of Medina Sheriff münevver, münevver Medina, Saudi Arabia, 1412H (1992).

12. Pejanović, R., Radović, G. (2011): Agrarna politika u Republici Srbiji u periodu tranzicije, Ekonomija teorija i praksa, Vol. 4, No. 1, pp. 29-38.

13. Pejanović, R., Radović, G., Tomaš, M., Maksimović, G., Krajinović, G., Jelić, V. (2010): Agricultural budget as a form of financing agriculture in the Republic of Serbia, Contemporary agriculture, Vol. 59, No. 1-2, pp. 206-213.

14. Statistical Office of the Republic of Serbia (2013b): Census of Agriculture 2012, Agriculture in the Republic of Serbia, SORS, Belgrade.

15. Štulanović M., Hadžić F. (2007): Osnovi islamske ekonomije i financija, Islamski pedagoški fakultet u Bihaću.

16. Title of the Law on Incentives in Agriculture and Rural Development, Official Gazette of the Republic of Serbia no. 10/2013.

17. Vladisavljević, V., Knežević, M., Divac, G. (2017): Pravna forma ugovora o finansijskom lizingu, Oditor, Vol. 3, No. 2, pp. 67-77.

18. Vlado, L. (2008): Financijske institucije i tržišta, Zagreb.

19. Zamir I., Abbas M. (2009): Islamske financije teorija i praksa, MATE d.o.o. Zagreb, p. 71-90, p. 164-165.

20. Zamir, I., Mirakhor, A. (2009): Introduction to Islamic Finance - Theory and Practice, Mate doo, Zagreb. 


\title{
ISLAMSKE BANKE I FINASIJSKE INSTITUCIJE I MOGUĆNOST FINANSIRANJA POLJOPRIVREDE U REPUBLICI SRBIJI
}

\author{
Bahrija Kačar ${ }^{4}$, Jasmina Curić5 ${ }^{5}$, Selma Ikićc
}

\section{Rezime}

Finansiranje kakoprivrede tako $i$ poljoprivrede $u$ Republici Srbiji u dosadašnjem $i$ aktuelnom periodurealizovalo i realizuje se uz finansijsku i kreditnu podršku države, kao i putem skupih kreditaposlovnih banaka i finansijskog lizinga. Imajući u vidu proizvodne resurse, značaj poljoprivrede za nacionalnuprivredu i zaposlenost stanovništva, a da finansiranje poljoprivredeu Republici Srbiji, na sadašnjem nivou njene razvijenosti, treba dabude realizovano uz podršku države. Država treba daradi na osnivanje specijalizovanepoljoprivredne banke izakonskom regulativom omogući dolazakfinansijskih institucija koje će plasirati sredstva po povoljnim uslovima kao što su Islamske finansijske institucije.

Islamske finansijske institucije, kod plasmana finansijskih sredstava tj kredita ne koriste kamatu, to je po islamskom učenju nepravedno i neprihvatljivo. Teoretičari Islamske ekonomije vide alternativu u temeljnim vrednostima i učenjima Islama, Kur 'anu i Sunnetu, koji strogo zabranjuju kamatu.

Islamska banka može ostvariti i određene komparativne prednosti u odnosu na druge domaće banke. Ona je u poziciji da može uspostaviti kvalitetne poslovne veze sa klijentima iz Muslimanskih zemalja kako kod nastupa domaćih kompanija na njihovim tržištima, tako $i$ kod nastupa kompanija iz Muslimanskih zemalja na tržištu Republike Srbije. Dalju prednost ove banke vidimo i u tome što bi jedan od njenih osnivača i IDB - Islamic Development Bank - vodeća razvojna banka Muslimanskog svijeta čija iskustva u realizaciji razvojnih projekata za Srbiju mogu biti od velike koristi. Ipak, najveći potencijal Islamska banka ima u uspostavljenju i razvoju poslovnih odnosa $i$ saradnje sa sve većim brojem finansijskih $i$ drugih institucija koje svoje poslovanje zasnivaju na principima šerijata.

Ključne reči: Poljoprivreda, kreditiranje poljoprivrede, islamske finansijske institucije, islamske bake

4 Dr Bahrija Kačar, asistent, Departman za ekonomske nauke, Državni univerzitet u Novom Pazaru, Ulica Vuka Karadžića bb, 36300 Novi Pazar, Srbija, Telefon:+381 62333 808, E-mail: bahrijakacarnp@yahoo.com

5 Dr Curić Jasmina, asistent, Departman za hemijsko - tehnološke nauke, Državni univerzitet u Novom Pazaru, Ulica Vuka Karadžića bb, 36300 Novi Pazar, Srbija, Telefon: +381 66631 52 70, E-mail: jasminacuric65@gmail.com

6 Mr Ikić Selma, saradnik, Odeljenje za lokalni ekonomski razvoj, Gradska uprava Novi Pazar, Ulica Stevana Nemanja br. 2, 36300 Novi Pazar, Srbija, Telefon: +381 62488 740, E-mail: selma.ikic@novipazar.org.rs 